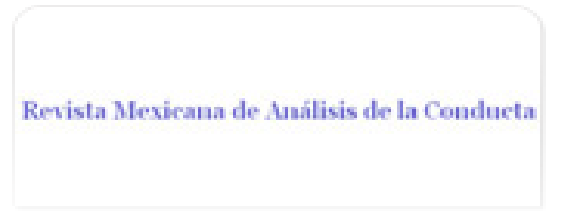

Revista Mexicana de Análisis de la Conducta ISSN: 0185-4534

editora@rmac-mx.org

Sociedad Mexicana de Análisis de la Conducta México

Pérez-García, Georgina; Liy-Salmerón, Gustavo; Meneses, Alfredo

Receptores serotonérgicos y memoria

Revista Mexicana de Análisis de la Conducta, vol. 32, núm. 2, diciembre, 2006, pp. 241-269

Sociedad Mexicana de Análisis de la Conducta

Guadalajara, México

Disponible en: http://www.redalyc.org/articulo.oa?id=59332210

- Cómo citar el artículo

- Número completo

- Más información del artículo

- Página de la revista en redalyc.org

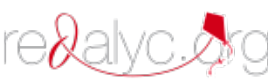

Sistema de Información Científica

Red de Revistas Científicas de América Latina, el Caribe, España y Portugal Proyecto académico sin fines de lucro, desarrollado bajo la iniciativa de acceso abierto 


\title{
RECEPTORES SEROTONÉRGICOS Y MEMORIA
}

\author{
SEROTONERGIC RECEPTORS AND MEMORY \\ GEORGINA PÉREZ-GARCÍA, GUSTAVO LIY SALMERÓN \\ Y ALFREDO MENESES* \\ DEPARTAMENTO DE FARMACOBIOLOGÍA, \\ CINVESTAV-IPN
}

\begin{abstract}
RESUMEN
En recientes años, el aprendizaje y la memoria han sido objeto de estudio, teniendo como objetivos, el desarrollo de terapias que reviertan o prevengan el deterioro cognitivo. Diferentes sistemas de neurotransmisión (Ach, NA y 5-HT) participan en los procesos de aprendizaje y memoria. La serotonina (5hidroxitriptamina, 5-HT) proyecta a casi todas las áreas cerebrales y participa en procesos sensoriales, motores y conductuales, incluyendo aprendizaje y memoria. En este trabajo se revisa evidencia reciente de receptores serotonérgicos participantes en la formación de memoria. Por ejemplo receptores serotonérgicos como los $5-\mathrm{HT}_{1 \mathrm{~A}}, 5-\mathrm{HT}_{6}$ y $5-\mathrm{HT}_{7}$ se encuentran en estructuras importantes para la memoria como corteza frontal, hipocampo y núcleo del rafe dorsal. Se ha demostrado que la estimulación de receptores como los $5-\mathrm{HT}_{1 \mathrm{~A}}$ y $5-\mathrm{HT}_{7}$ facilita la formación de la memoria y/o revierten la amnesia. Tanto durante la formación de la memoria y en modelos farmacológicos de amnesia estos cambios parecen estar asociados a la producción de AMPc, la expresión del RNA mensajero y la proteína que se convierte en receptor. Los nuevos agonistas y antagonistas serotonérgicos nos permitirán la identificación de nuevos mecanismos farmacológicos y moleculares útiles en el tratamiento de alteraciones de la memoria.
\end{abstract}

* Depto Farmacobiología, CINVESTAV, Tenorios 235, Granjas Coapa, México 14330, Telefono: (52) 55-50612869, Fax: (52) 55-50612863. E-mail: ameneses@ms.ncom 


\begin{abstract}
In recent years learning and memory have been intensively studied, aiming to find pharmacological treatments to prevent or reverse cognitive impairment. Different neurotransmission systems (AC, NA, etc) participate in learning and memory processes. Serotonin (5-hydrotryptamine, 5-HT) projects to almost brain areas and participates in sensorial, motor and behavioral processes, including memory. In this work evidence is revised involving 5-HT receptors in memory formation. For instance, $5-\mathrm{HT}_{1 \mathrm{~A}}, 5-\mathrm{HT}_{6}$ and $5-\mathrm{HT}_{7}$ receptors are located in brain structures important for memory such as frontal cortex, hippocampus, and raphe nuclei. It has been demonstrated that stimulation of $5-\mathrm{HT}_{1 \mathrm{~A}}$ and $5-\mathrm{HT}_{7}$ receptors facilitates memory formation and/or reverses amnesia. Apparently memory formation or changes observed in pharmacological models of amnesia are associated to the modulation of cAMP production, expression of RNA messenger and the resulting receptor protein. New 5-HT receptor agonists and antagonists will allow identification of new pharmacological and molecular mechanisms useful in the treatment of memory alterations.
\end{abstract}

\title{
INTRODUCCIÓN
}

Ante el aumento en la expectativa de vida en la población humana, las enfermedades neurodegenerativas son un fenómeno de salud pública mundial. Entre estas alteraciones se encuentra la enfermedad de Alzheimer (EA), asociada a la vejez y el deterioro del aprendizaje y la memoria (Buckner, 2004). El objetivo de este trabajo es mostrar un panorama general del aprendizaje y la memoria así como recientes avances en la investigación de sus bases farmacológicas y moleculares, principalmente desde la perspectiva del neurotransmisor serotonina. Este neurotransmisor ha permitido observar importantes mecanismos moleculares de la memoria. Estudios hechos en invertebrados y mamíferos, incluyendo humanos, indican que el aprendizaje es la inducción de cambios neuronales, con manifestaciones en la conducta como consecuencia de la experiencia y la memoria es la capacidad (o función) que permite codificar, almacenar y recuperar la información (Domjan, 1998; Albright, 2000; Cahill, et al 2001; Buckner, 2004).

Desde la perspectiva de su contenido la memoria se clasifica en declarativa o explicita, y no-declarativa o Implícita. La primera se refiere a hechos, eventos, imágenes o lugares y que se recuerdan mediante un esfuerzo consciente (e.j. recordar la fecha de nacimiento de alguien). Se forma en el hipocampo y se almacena en la neocorteza. (Dickinson, 1984; Buckner, 2004). La segunda se forma independientemente del hipocampo, se refiere a las sensaciones, capacidades y habilidades que se recuerdan de manera 
involuntaria (Domjan, 1998; Kehoe, et al 2003). Por ejemplo, recordar como conducir un auto.

Por otra parte, desde la perspectiva del tiempo, la memoria se clasifica en: memoria a corto plazo (MCP) y Memoria a largo plazo (MLP): La primera se refiere al almacenamiento temporal de la información, como por ejemplo, un número telefónico y abarca períodos de segundos a horas. Tiene una capacidad de almacenamiento limitada, experimentalmente se ha demostrado que sólo pueden mantenerse entre 4 y 7 elementos (pueden ser letras por ejemplo) en ella. La MCP puede olvidarse o ser incorporada a la memoria de largo plazo cuando esta funciona en serie o linealmente (Izquierdo et al 2002; ver más adelante). Las posibles funciones de la MCP consisten en comparar e integrar la información que recibimos, con aquella que tenemos almacenada en la memoria a largo plazo (MLP). (Domjan, 1998; Nader, 2003). Otra función es la de práctica, ensayo o repetición el material recibido en la MCP, permitendo que las unidades de información recién adquiridas sean mantenidas por períodos más largos y pasen a formar parte de la MLP. Finalmente, la MCP a nivel intracelular y molecular se asocia a cambios sinápticos a corto plazo involucrando modificaciones covalentes de proteínas existentes, permitiendo la modificación de conexiones sinápticas (McDonald, et al 2004; Rodrigues et al., 2004).

La MLP almacena información que se conserva durante horas, días, semanas o incluso años, es ilimitada en cuanto a su capacidad y período de retención (Nader, 2003). En toda la escala filogética, la MLP requiere de la activación de la expresión de genes para la síntesis de nuevas proteínas y la formación de nuevas conexiones a nivel sináptico. Cabe destacar que, en contraste con la MCP, se bloquea la formación de la MLP con los inhibidores de la síntesis de proteínas o del RNA mensajero (Albright, et al 2000; Lynch, 2002; Routtenberg, et al 2005) por ejemplo, la anisomicina o el 5, 6-di cloro1,1 beta-D-ribobezidozole (DRB). Un ejemplo de MLP es recordar el nombre y aspecto de nuestra familia.

\section{FORMACION DE LA MEMORIA}

El procesamiento de la información pasa por las siguientes etapas: adquisición, codificación, consolidación, almacenamiento y recuperación de la memoria (Cahill, 2001). La codificación se refiere al proceso de adquisición de la información que la transforma en señales neuroquímicas y/o eléctricas a través de varias estructuras del SNC (por ejemplo de corteza somatosensorial al hipocampo y amígdala), utilizando diferentes sistemas de neurotransmisión (como el glutamatérgico, colinérgico y serotonérgico). La consolidación es el proceso por el cual la información codificada pasa por una etapa lábil depen- 
diente del tiempo, que incluye la síntesis del RNAm y de proteínas (Dash, et al 2004; Alberini, 2005). Cuando la información codificada y almacenada es requerida se recupera, a esto se le llama recuerdo o evocación (Moser, 1999; McDonald, et al 2004).

\section{ESTRUCTURAS CEREBRALES INVOLUCRADAS EN EL APRENDIZAJE Y LA MEMORIA Y ALGUNAS DE SUS DISFUNCIONES}

Diversas líneas de investigación (Buhot, et al 1997; 1999; Kandel, 2001) han permitido establecer que la formación de la memoria explícita ocurre en el hipocampo (CA1-CA3, Giro dentado) y estructuras subyacentes a este (cortezas entorhinal, perhinal, parahipocampal), asícomo al subículo y la amígdala. Para el almacenamiento de la memoria se ocupan áreas corticales como la corteza prefrontal medial, parietal posterior, retroesplenial y prelímbica (Meneses, 1997; Lamprecht, et al 2004). A este conjunto de estructuras se le llama circuito de la memoria (Buhot, et al 1999). Este describe el paso de la información de la corteza someto-sensorial al hipocampo y la amígdala, para que se consolide esta información en memoria y sea almacenada en la corteza prefrontal y temporal. Dentro de este circuito de la memoria participan varios sistemas de neurotransmisión como son: Ach, Glutamato, GABA, DA y 5-HT entre otros (Berger et al., 2004; Mc Donald et al., 2004).

Entre las diversas disfunciones que afectan la memoria esta la amnesia, la cual es la pérdida parcial o total de la memoria declarativa resultado de trastornos funcionales o mentales. Por otro lado, la demencia se define como la pérdida de las funciones intelectuales incluyendo memoria de explícita. Asimismo la enfermedad de Alzheimer es un padecimiento neurodegenerativo progresivo, caracterizado por la pérdida creciente de este tipo de memoria, probablemente ligada al deposito de placas amiloides, marañas de nuerofibrillas y deficiencias colinérgicas y serotonérgicas, lo cual eventualmente produce la muerte de neuronas en áreas cerebrales relacionadas a la memoria (Buckner, et al 2004; Kopelman, et al 2002).

\section{MODELOS CONDUCTUALES PARA EL ESTUDIO DE LA MEMORIA}

De las herramientas que se utilizan en la investigación del aprendizaje y la memoria, se encuentran los modelos animales que evalúan la conducta (innata, adquirida o espontánea) y a través de ella el aprendizaje asociativo y el espacial (Myhrer, 2003), que incluye evitación pasiva, el tanque con agua de Morris, etc. Los modelos de aprendizaje en animales son útiles para determinar la relación entre memorias específicas, sus mecanismos y las estructuras 
cerebrales involucradas. El aprendizaje asociativo se define como la relación que el animal establece entre varios eventos e incluye al condicionamiento clásico o pavloviano y al condicionamiento instrumental u operante (Davis et al 1977; Dickinson, 1984; Domjan, 1998; Shors et al 2000). Los componentes del condicionamiento clásico son el estímulo condicionado (EC) e incondicionado $(E I)$, al principio del condicionamiento el primero es neutro y no produce respuestas por si sólo, mientras que el segundo desencadena la respuesta incondicionada por sí mismo. El apareamiento o sesión de condicionamiento, sucede cuando a un organismo se le suministran una o varias presentaciones pareadas de los estímulos mencionados; es decir el EC seguido del El. La respuesta condicionada (RC) es el resultado del apareamiento de estímulos, donde el EC es capaz de evocar la respuesta por si mismo (Domjan, 1998; Kehoe et al, 2003). Por otra parte, el condicionamiento operante o instrumental se basa en la asociación entre respuestas y estímulos (Davis et al, 1977), ya que opera sobre el medio ambiente que se mantiene o bien no se usa como resultado de sus consecuencias. Así, una respuesta evocada por el sujeto es seguida por la presentación o entrega de un estímulo incondicionado, de manera que después de repetidas presentaciones o ensayos, la probabilidad que la respuesta ocurra aumenta. Los componentes del condicionamiento operante son la respuesta condicionada (RC) y estímulo condicionado (EC). Al principio del condicionamiento la respuesta del sujeto ocurre al azar ante la ausencia de un estímulo específico, el El desencadena la respuesta por sí mismo, aumentando o disminuyendo su ocurrencia. La contingencia o sesión de condicionamiento, es la entrega inmediata del El que sigue a la respuesta por el individuo. La evocación o prueba, se realiza tiempo después de la sesiones de condicionamiento y consiste en exponer al sujeto sólo al ambiente de prueba y evaluar las respuestas. La respuesta instrumental u operante $(\boldsymbol{R} \boldsymbol{I})$ es el resultado del apareamiento de respuestas con estímulos, donde el grado de la ocurrencia de la RI depende el mantenerla o extinguirla. Los componentes del condicionamiento clásico y del instrumental se pueden estudiar en un mismo paradigma conductual llamado automoldeamiento, donde existe una relación entre estímulos (EC-EI) y respuesta-estímulo (RI-EI) que produce un aprendizaje rápidamente y puede ser casi completamente automatizado.

\section{AUTOMOLDEAMIENTO}

El automoldeamiento ("autoshaping") es un aprendizaje asociativo observado en varias especies (pichones, ratas, ratones y humanos; Meneses, 1987) y se ha empleado en el estudio de los procesos de aprendizaje y memoria con manipulaciones farmacológicas y neuroquímicas así como en el déficit en el apre- 
ndizaje y la memoria (Meneses, 1997; 2003). Para moldear o entrenar al sujeto ante una nueva conducta, se administra un "reforzador" (como por ejemplo comida) de forma gradual ante conductas que se asemejen a la deseada. En el caso del automoldeamiento, el sujeto se auto-enseña una conducta nueva. Los animales privados de alimento, en una cámara experimental se orientan, acercan y, eventualmente, hacen contacto con señales relacionadas con algún tipo de satisfactor (calor, comida, agua, entre otros; Davis, 1977). El automoldeamiento en ratas y monos puede combinar el condicionamiento clásico (asociación de dos estímulos) y el condicionamiento operante (asociación respuesta-estímulo) y ocurre lo siguiente: La tecla o palanca iluminada es un EC que precede la entrega del El (la comida) y que después de varios ensayos, el animal emite una respuesta condicionada (RC) al presionar la palanca (EC), demostrando así que los animales emiten la primera RC como resultado de la asociación pavloviana entre estímulos (ver figura 1). A continuación, la asociación instrumental (R-EI) tiende a regularizar la emisión de la RC; por ende, la $\mathrm{RC}$ se establece como resultado de la asociación entre los estímulos y la respuesta automoldeada o aprendizaje respuesta-estímulo incondicionado (Domjan, 1998b;Kehoe et al, 2003). El automoldeamiento puede evaluar la memoria y es una herramienta útil para observar cambios en sistemas de neurotransmisión como el colinérgico, glutamatérgico y serotonérgico provocados por diversos fármacos (Meneses A., 2003).

\section{LA SEROTONINA Y LA MEMORIA}

La serotonina es una indolamina que no atraviesa la barrera hematoencefálica fácilmente, sin embargo, como se descubrió que la 5-HT estaba presente en cerebro se pensó que era sintetizada localmente (Goodman and Gilman, 2002). Las neuronas toman el aminoácido L-triptofano de la sangre por un mecanismo de transporte facilitado y lo convierten en serotonina (Baumgarten et al, 2000). La serotonina o 5-Hidroxitriptamina (5-HT) se sintetiza por una vía de dos etapas a partir del aminoácido esencial triptófano. Esta molécula esta involucrada en una variedad de procesos sensoriales, motores y conductuales en distintas funciones (e.j. ritmos circádicos, sueño) y patologías (e.j. depresión, esquizofrenia, dolor) que la hacen blanco de múltiples investigaciones con diferente enfoque (revisado en Thomas et al, 2004).

\section{NEUROANATOMÍA DEL SISTEMA SEROTONÉRGICO}

Las neuronas serotonérgicas contienen las enzimas que convierten al L-triptófano en serotonina, neurotransmisor (NT) del SNC y SNP (Jacobs, 1992). 
Utilizando técnicas de inmunohistofluorescencia se han podido identificar los núcleos de las neuronas serotonérgicas que de acuerdo a su origen embrionario, se han clasificado en dos grupos superior e inferior. El primero inerva casi todo el cerebro, procede del mescencéfalo y esta constituido por cuatro subgrupos: el grupo caudal lineal (NCL), el núcleo rafe medio (NRM), el núcleo rafe dorsal (NRD) y el núcleo lemniscus (NLM). El grupo inferior se origina del mielencéfalo y esta constituido por cinco subgrupos: núcleo de rafe obscurus (NRO), núcleo de rafe pallidus (NRP), núcleo de rafe magnus (NRMa), núcleo ventro lateral medular (NVLM) y núcleo reticular intermedio (NRI). Los diversos efectos de este NT están relacionados con las extensas proyecciones de la neuronas serotonérgicas a través del cerebro y la expresión de distintos subtipos receptores de la serotonina (Van Wijngaarden, 1990).

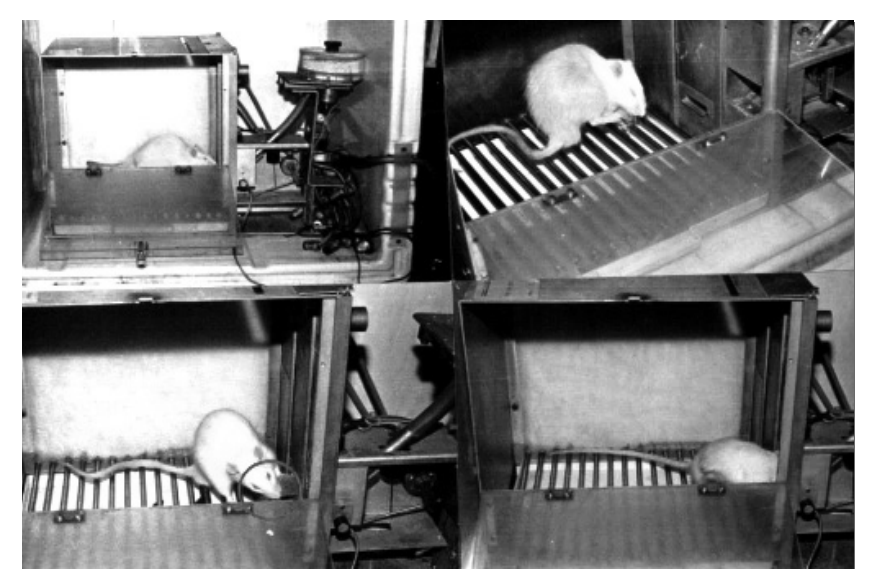

Figura. 1. Muestra la caja experimental, así como las diferentes etapas del automoldeamiento. En el primer cuadro (arriba, izquierda) el animal privado de alimento es introducido a la cámara experimental. En el segundo cuadro (arriba, derecha) se aprecian los 2 estímulos: la palanca retráctil (EC) y el pellet de comida (El) en el comedero. En el tercer cuadro (abajo, izquierda) se observa al animal presionando la palanca retráctil. En el cuarto cuadro (abajo, derecha)el animal recoje el pellet de comida después de haber oprimido la palanca retráctil.

\section{TIPOS DE RECEPTORES SEROTONÉRGICOS Y MEMORIA}

Progresos recientes en la biología molecular del sistema serotonérgico han llevado a reclasificar sus receptores (Hoyer, 2002), basándose en criterios 
operacionales (agonista y antagonistas), estructurales (estructura protéica del receptor) y transduccionales (mecanismos de transducción acoplados al receptores), ha propuesto la clasificación y nomenclatura de catorce subtipos dentro de siete familias de receptores a serotonina en mamíferos (Bradley, 1986; Hoyer et al., 2002). Existe evidencia que la manipulación farmacológica de algunos sistemas de neurotransmisión (e.j. ACh, serotonina, glutamato) puede influenciar el aprendizaje y la memoria en diversas especies animales incluyendo humanos, ratas e invertebrados. Basándose en sus amplias proyecciones en el cerebro, la serotonina parece tener un papel importante como neuromodulador en los diferentes estadíos del aprendizaje y la memoria; es decir en los mecanismos neurobiológicos involucrados en los procesos de adquisición, consolidación y evocación de la memoria (Berger et al., 2004;Dash PK, 2004).

\section{APRENDIZAJE, MEMORIA Y GENES}

Existe evidencia que el aprendizaje y la memoria inducen cambios por medio de moléculas producidas en el SNC, como son neurotransmisores, neuropéptidos, etc., los cuales interactúan con receptores neuronales para inducir cambios en la densidad de receptores y, con esto, en la plasticidad de las neuronas (Riedel, 1999; Kandel, 2001). El uso de nuevas técnicas y aproximaciones han permitido estudiar los mecanismos moleculares del aprendizaje y la memoria que presumiblemente son activados por los mencionados neurotransmisores (Berger et al., 2004). Así, asociados a la formación de memoria se han observado cambios en la expresión de genes, en la síntesis de proteínas, en la morfología de la neurona, aumento o disminución en el disparo y aumento o disminución en la expresión de receptores en membrana, entre otros (Kandel, 2001). Por ejemplo, se ha encontrado que en vertebrados (ratas, ratones y en aves) e invetebrados (como la Aplysia un molusco marino), en el aprendizaje y la formación de la memoria poseen un sustrato molecular particular (Routtenberg et al, 2005). Particularmente en el caso de la Aplysia la serotonina y varios de sus receptores desempeñan un papel muy importante en los procesos de la memoria.

De hecho, sin importar la especie animal se ha podido establecer que la MCP que dura de minutos a horas, requiere de modificaciones post-traduccionales a proteínas existentes pero no de la síntesis de nuevas macromoléculas. En cambio, la MLP que dura de horas a años, requiere de la inducción de expresión de genes, síntesis del mensajero del receptor (RNAm) y de nuevas proteínas, los cuales pueden inducir el fortalecimiento de conexiones sinápticas, modificando así la eficiencia de la transmisión sináptica (Cavallaro et al, 2001; Cammarota et al, 2005). En efecto, estudios usando 
varias especies y tareas conductuales de aprendizaje y en las cascadas de señalización intracelular memoria han identificado cambios en y la plasticidad neuronal (Kandel, 2001). Por ejemplo, cuando la serotonina endógena se une al receptor acoplado a proteínas $G$ y a segundos mensajeros como $A M P c$, se activan moléculas como: la protein cinasa $A(P K A)$, la protein cinasa $C(P K C)$, la cinasa regulada por calcio/calmodulina (CaMKII) y la cinasa reguladora de la señal extracelular (Erk). Para formar la MLP, al activarse alguna de estas moléculas se translocan al núcleo y fosforilan factores de trascripción tempranos (Lamprecht, 1999; Micheau y Riedel 1999) como el elemento de respuesta al AMPC (CREB por sus siglas en inglés). Se ha encontrado que el CREB es fosforilado en hipocampo, amígdala y corteza parietal durante la prueba de aprendizaje de miedo (lgaz, et al 2004; Dash, et al 2004). Durante las mencionadas pruebas y laberinto espacial de Barnes, en rata y ratón, se ha encontrado CaMKII activada en hipocampo, amígdala y estriado (Vianna, et al 2000). La regulación coordinada de estos factores de transcripción permite la inducción rápida de genes de expresión temprana de respuesta inmediata, mismos que parecen inducir la expresión de genes tardíos. Esto se pudo determinar porque los genes de expresión temprana (como factores de transcripción) se sintetizan durante la fase de consolidación. Los genes de expresión temprana (o factores de transcripción tempranos, Tischmeyer y Grimm 1999) son muy importantes, ya que los productos protéicos de estos van a inducir y mantener la expresión de genes tardíos, los cuales inducen y mantienen el crecimiento y fortalecimiento de nuevas conexiones sinápticas, así formando y manteniendo la MLP (Dever, 2002; Dash et al, 2004;Igaz et al, 2004).

La fosforilación (esto es la incorporación de fosfatos a sitios de fosforilación en las moléculas) y activación de factores de trascripción incluye la inducción de la expresión de diversos genes como son: la proteína asociada a la regulación del citoesqueleto (arc), c-fos (un indicador precoz de la activación de neuronas, que es un útil marcador de trascripción y activación neuronal), zif-268 y sintaxina 1B entre otros. Así, el producto final o la proteína efectora de estas expresiones proveen a la neurona de características que modifican los mecanismos de almacenamiento de la información más eficientemente (Routtenberg, 2005; Szapiro, et al 2002). Cabe destacar que la expresión de los genes y la síntesis de proteínas ocurren en el soma; en cambio, como resultado del transporte de RNAm y ribosomas, la traducción ocurre en las dendritas, cuyo producto (proteínas nuevas) es requerido en la sinapsis (Klann, et al 2004). Sin embargo, se desconoce si para todos los productos son sintetizadas estas moléculas en el soma y transportados a las terminales o algunos pudieran ser sintetizados en este mismo sitio.

La evidencia mas completa ha sido obtenida en rata e indica que la MLP está mediada por la síntesis de proteínas (previa activación transcripcional) 
en una variedad de paradigmas conductuales (Kandel, 2001; Lamprecht, 2004). De manera que uno de los primeros pasos moleculares ante la formación de la MLP es la activación de algunos factores de trascripción (como CREB), los cuales inducen la expresión de otros reguladores de la expresión génica (por ejemplo c-fos), los que a su vez, guían la expresión de conjuntos específicos de genes efectores. Las vías de transducción de señales deben de tener un mecanismo que permite integrar temporal y espacialmente los estímulos que inducen cambios en la expresión de genes. Uno de tales mecanismos puede ser la síntesis del ARN mensajero (ARNm), que es el molde para la síntesis de proteínas (ver figura 2).

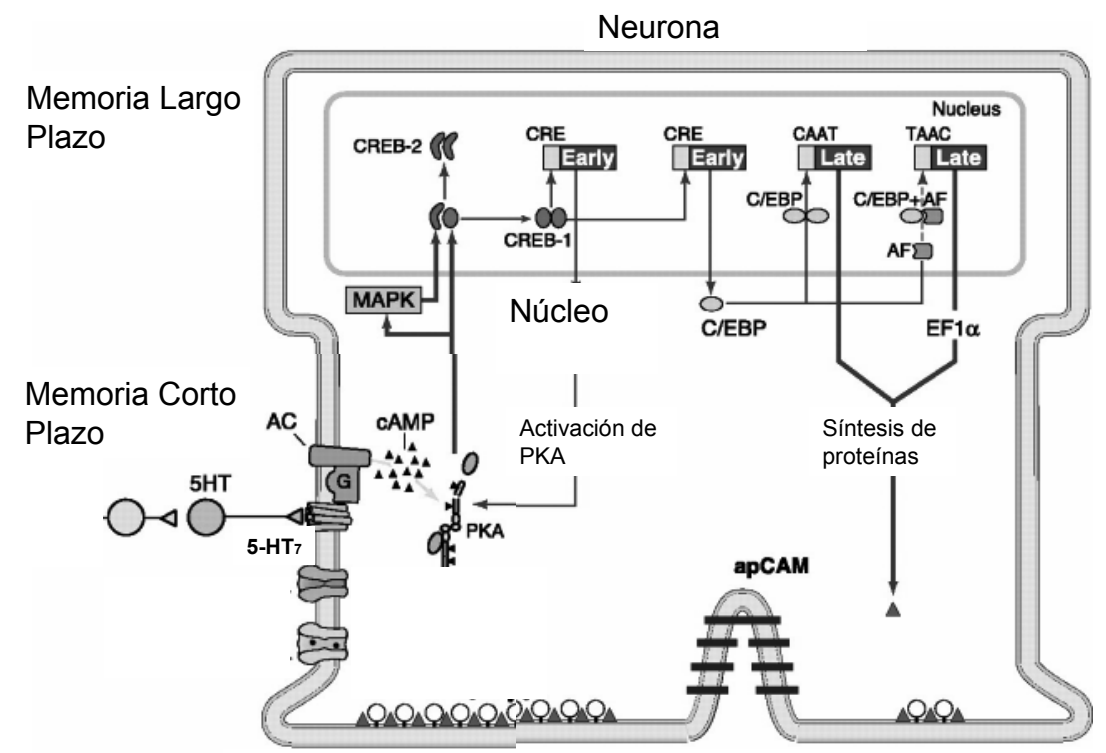

Figura 2. Describe los eventos moleculares de la formación de la MCP y MLP (Tomado de Kandel, 2001). La MCP ocurre cuando la serotonina endógena activa receptores serotonérgicos (como el 5-HT ) aumentando el AMPc. Cuando continua estimulándose el receptor y aumentando el AMPc, este activa la PKA, translocándose al núcleo y promoviendo factores te trascripción tempranos como el CREB, induciendo la síntesis de nuevas proteínas.

Mas aún, las tareas conductuales de aprendizaje (laberinto radial, condicionamiento de miedo, entre otras) inducen cambios morfológicos discretos en estructuras cerebrales específicas, como en el hipocampo, la amígdala, la corteza prefrontal, entre otras. De hecho, el hipocampo provee de alma- 
cenamiento temporal de la memoria para proyectarla a la corteza (Alberini, 2005) y cuando se lesiona esta estructura o se bloquea la síntesis de proteínas localmente se induce una disfunción en la MLP, como en la amnesia (Morton et al 1985; Santucci et al, 2004).

La síntesis de proteínas es tan importante para la consolidación de la memoria que en la década de los 1960 s se reportó que la administración de anisomicina, ciclohexamida, puromicina o la acetilcicloheximida (todos antibióticos), inhiben la formación de la MLP (por esta inhibición de la síntesis protéica; Davis y Squire, 1984). Una sola administración de anisomicina inhibe la síntesis de proteínas en un $80 \%$ por dos o más horas y sucesivas administraciones prolongan esta inhibición, induciendo amnesia a los animales tratados con estos fármacos (Routtenberg, 2005). Mas recientemente se ha demostrado la inducción de expresión de genes en la amígdala basolateral (BLA), durante la formación de memoria durante el aprendizaje de miedo, la cual es bloqueada por la inhibición de síntesis de proteínas (Stork, 1999). Asimismo, el uso de bloqueadores de cinasas como la PKA (Rp-cAMPs) y de MAPK (PD098059) afectan la formación de memoria en el condicionamiento de aversión pasiva (Vianna, et al 2000). En conjunto esto quiere decir que la memoria puede ser afectada en distintos puntos de la cascada de señalización celular (desde bloqueo de receptores, análogos o bloqueadores de cinasas hasta inhibidores de la síntesis de proteínas).

Por otro lado, se ha utilizado la mosca de la fruta (Drosophila) como modelo de estudio porque se puede realizar manipulaciones genéticas (como inducción de mutaciones, deleciones de un gen, entre otras; Kandel, 2001; Igaz et al 2004) en el animal y el tiempo de expresión de los cambios es muy corto en comparación con otros modelos animales (ratones por ejemplo). Utilizando Drosophila con modificaciones en los genes se han encontrado deficiencias en varios tipos de tareas conductuales que evalúan el aprendizaje y la memoria (Leil, 2002; 2003), incluyendo condicionamiento clásico (Kandel, 2001).

Los anteriores avances ha permitido incorporar nuevas herramientas moleculares para ser usadas en modelos animales de diversas enfermedades para evaluar distintos tratamientos farmacológicos (e.j. agentes colinérgicos) con distintas pruebas conductuales (water maze, T maze, entre otras; Morton, 2005). Otras técnicas de análisis moleculares son la PCR, electroforesis, microarreglos, entre otras) (Dash, 2004; Izquierdo et al, 2002; Igaz et al, 2004; Morton, 2005). Además de los cambios moleculares (Berger et al., 2004), en el estudio de la memoria se usan registros electrofisiológicos y análisis de imágenes (como la tomografía de emisión de positrones, PET), identificando cambios durante la codificación del la información (aprendizaje), la consolidación y durante la recuperación de memoria (Albright, 2000). Estos cambios se refieren a un aumento en la actividad neural (traducida como apertura y 
cierre de canales sensibles a iones) y aumento de la actividad cerebral (traducida como incorporación de moléculas en distintas estructuras cerebrales). No obstante los enormes avances mencionados se desconoce como la serotonina inicia la cascada de señalización en mamíferos durante la formación de la memoria.

\section{SEROTONINA Y LA CASCADA DE SEÑALIZACIÓN EN MAMÍFEROS DURANTE LA FORMACIÓN DE LA MEMORIA}

Actualmente se ha aceptado que varios receptores serotonérgicos participan en la formación de memoria en distintos estadíos del aprendizaje (adquisición y/o consolidación de esta) facilitándola o bloqueándola. Varios de tales receptores serotonérgicos han llamado la atención incluyendo a los $5-\mathrm{HT}_{1 \mathrm{~A}}$, $5-\mathrm{HT}_{4}, 5-\mathrm{HT}_{6}$ y $5-\mathrm{HT}_{7}$ porque se les ha involucrado en funciones y disfunciones específicas, entre ellas, la formación de la memoria y en los desórdenes cognitivos de la enfermedad de Alzheimer y de la esquizofrenia (Garcia-Ostas et al 2000; Heidmann et al, 1997; Lovenberg et al, 1993; Shen Y, 1993). Sólo la reciente identificación y desarrollo de agonistas y antagonistas selectivos para varios de estos receptores, ha permitido investigar sus funciones y repercusiones en SNC como el aprendizaje y la memoria (Slassi et al., 2004; Thomas, 2004). Estos receptores están acoplados a proteínas Gi (5$\left.\mathrm{HT}_{1 \mathrm{~A}}\right) \circ \mathrm{Gs}\left(5-\mathrm{HT}_{4}, 5-\mathrm{HT}_{6}\right.$ y $\left.5-\mathrm{HT}_{7}\right)$, que a su vez inhibe o estimula el adenilato ciclasa (AC), respectivamente, disminuyendo o aumentando el AMPc. La producción del AMPc modula diferentes protein cinasas como la PKA. La PKA y la PKC que se han asociado a activación de genes y a la formación de la memoria (Kandel, 2001). Se han encontrado altas densidades de estos receptores en el SNC, en corteza, septum, núcleo caudado, hipotálamo, hipocampo, rafe dorsal, ganglios basales, amígdala entre otras (Hoyer et al, 2002; Varnas et al, 2004). Estas distribuciones son similares en varias especies como rata, ratón, cobayo, humano y son importantes para la adquisición y consolidación de la memoria (Manuel Apolinar, 2004; Slassi et al., 2004). Hasta aquí se han revisado distintos trabajos que muestran evidencias de la participación de la serotonina en el aprendizaje y la memoria, sin embargo tales trabajos han buscado la relación de memoria y otros neurotransmisores como acetilcolina (ACh) y principalmente glutamato (Lamprecht y LeDoux, 2004). A este hecho se pueden destacar algunas limitaciones teóricas y practicas como son el uso de indicadores inespecíficos de la actividad genómica neural (como el c-fos). Asimismo para el análisis conductual y farmacológico el utilizar animales diferentes a aquellos empleados en el análisis molecular dificulta el estudio del sustrato molecular de la memoria (Cavallaro et al 2002; Robles, 2003; Moyano et al 2005). Quizás mucho más importantemente es el 
hecho que la investigación de la serotonina y su papel en la memoria y sus bases moleculares han sido poco explorada. Por lo tanto en el laboratorio hemos intentado aportar evidencias del sustrato molecular de la memoria desde una perspectiva de este neurotransmisor.

Al revisar todos los antecedentes es importante hacer la pregunta si en la formación de la MLP y en modelos farmacológicos de amnesia, la estimulación o el bloqueo de los receptores $5-\mathrm{HT}_{1 \mathrm{~A}}, 5-\mathrm{HT}_{4}, 5-\mathrm{HT}_{6}$ y $5-\mathrm{HT}_{7}$ pueden producir cambios en la memoria y en la expresión del gen de estos receptores (ver figura 3). Para abordar experimentalmente estas cuestiones se propone realizar los experimentos (MLP y moleculares) en el mismo animal (muestras no homogenizadas) y analizar la expresión del RNAm de los mencionados receptores porque es un indicador preciso de la activación de la síntesis de estos receptores (ver memoria y genes) utilizando las metodologías revisadas en Chen y colaboradores 1998; y Sambrook y Russell 2001.
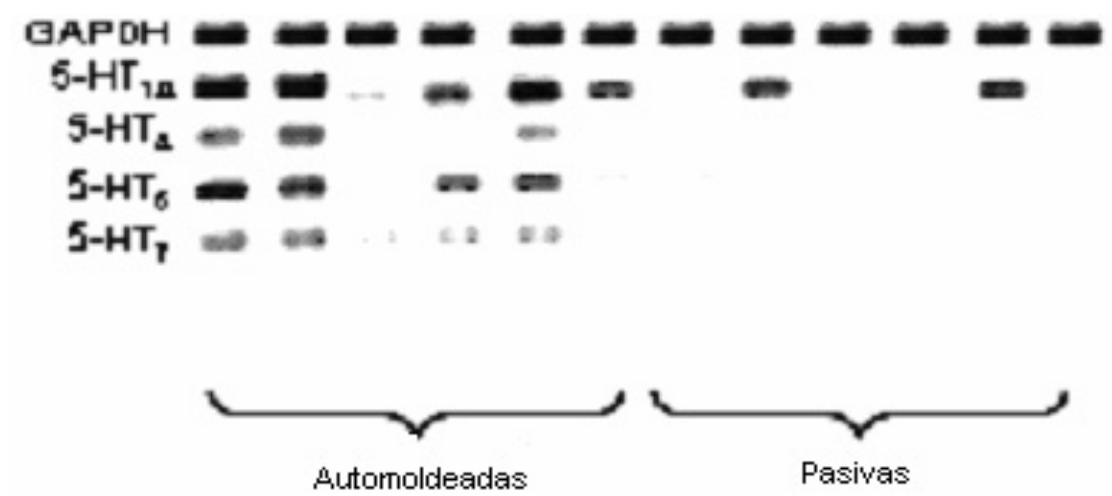

Figura.3. Muestra la expresión del RNAm de los receptores 5-HT $\mathrm{HT}_{4}, 5-\mathrm{HT}_{6}$ y $5-\mathrm{HT}_{7}$ y de GAPDH como su control (electroforesis representativa del RT-PCR) de las estructuras cerebrales rafe (RAF), HIP (hipocampo) y CPF (corteza prefrontal) de animales sometidos a automoldeamiento y animales pasivos o no entrenados.

\section{MLP Y SEROTONINA}

Recientes resultados de un estudio ex vivo, indican que la formación de la memoria automoldeada (ver sección aprendizaje asociativo) aumenta la expresión de receptores serotonérgicos como los $\mathrm{HT}_{1 \mathrm{~A}}, 5-\mathrm{HT}_{4}, 5-\mathrm{HT}_{6}$ y $5-\mathrm{HT}_{7}$, comparados con animales sin aprendizaje en la corteza prefrontal, hipocampo y núcleos del rafe (Perez-Garcia et al, 2006). En este contexto, la expresión 
del receptor $5-\mathrm{HT}_{7}$ llama particularmente la atención porque es diferencial por estructuras y por tratamiento, razon por la cual se exploro con más profundidad. El análisis de la expresión (de genes, permitió definir la expresión génica) del receptor $5-\mathrm{HT}_{7}$ en regiones particulares del cerebro (núcleos del rafe, hipocampo, CPF), en animales con y sin aprendizaje, y con diferentes tratamientos farmacológicos permitió concluir que tanto el aprendizaje como la estimulación del receptor $5-\mathrm{HT}_{7}$ con el AS 19 induce la expresión del gen de este mismo receptor (el $5-\mathrm{HT}_{7}$ ). El análisis en conjunto mostró la relación entre la formación de la memoria, afinidad de los fármacos por los receptores y la expresión selectiva del RNAm (ver figura 4).

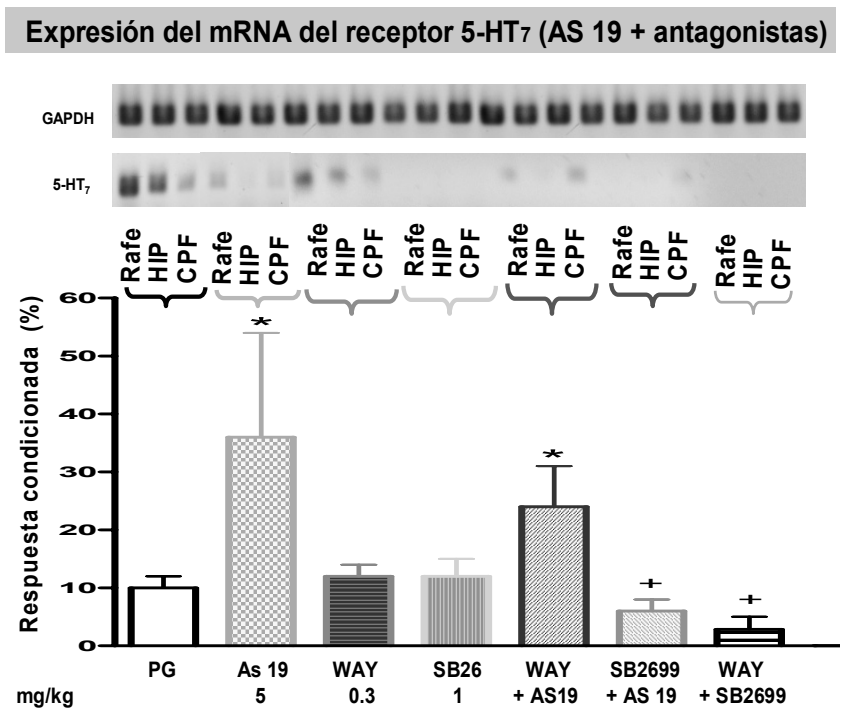

Figura 4. En la parte superior se muestra la expresión del RNAm del receptor 5-HT y GAPDH como su control (electroforesis representativa del RT$P C R$ ) de los animales entrenados con automoldeamiento y además tratados con AS19 y antagonistas (rafe, HIP (hipocampo) y CPF (corteza prefrontal). En la parte de abajo se muestra los animales correspondientes de los efectos conductuales del AS 19 (s.c.) así como SB-269970 y WAY100635 (i.p.) así como su interacción con el agonista en la tarea de automoldeamiento. Se muestra la media ( $\pm E S$ ) de la respuesta condicionada (CR \%). La administración de estos antagonistas bloquea el efecto facilitador del AS 19. La $n$ fue de 8 animales y fueron analizadas con la prueba de ANOVA, seguida por la prueba Tukey, ${ }^{*} p<0.05$ control salino vs. antagonista receptor $5-H T_{7}$ y $5-H T_{1 A)}$. 
El AS 19 (2S)-(+)-8-(1,3,5-Trimethylpyrazolin-4-yl)-2-(dimethylamino) tetralin (Sanin et al 2003) de los laboratorios Tocris es un agonista con alta afinidad para los receptores $5-\mathrm{HT}_{7}$ con una pKi=9.08 (información de Tocris) y que aumenta los niveles intracelulares del AMPc (Holmberg et al., 2004; ver Pérez-Garcia y Meneses, 2005), una respuesta asociada a la estimulación de los receptores $5-\mathrm{HT}_{7}$ (Hoyer y cols., 2002). En este laboratorio se encontró aumento en la respuesta condicionada (RC); es decir en la facilitación de la formación de memoria. Las dosis utilizadas para la curva dosis-respuesta del AS $19 \mathrm{mg} / \mathrm{kg}$ fueron $0.5,1,5$ y 10, siendo únicamente la dosis de $5 \mathrm{mg} /$ $\mathrm{kg}$ la que produjo un efecto conductual estadísticamente significativo, al facilitar la formación de la memoria. Este efecto facilitador de la formación de la memoria de largo plazo fue bloqueado por el SB-269970, pero no por el WAY100635, lo que nos indica que el efecto es mediado por la activación de los receptores $5-\mathrm{HT}_{7}$ y no por el $5-\mathrm{HT}_{1 \mathrm{~A}}$. Estos datos confirman la evidencia obtenida con el 8-OH-DPAT que también facilitó la formación de la memoria, un efecto bloqueado por antagonistas $5-\mathrm{HT}_{1 \mathrm{~A}}$ y $5-\mathrm{HT}_{7}$ (Meneses 1997;2001; 2004). Este trabajo muestra el uso potencial del AS 19 para estimular el receptor $5-\mathrm{HT}_{7}$, si bien es necesario, desarrollar para un futuro, experimentos con dosis logarítmicas e intermedias.

\section{ÁREAS CEREBRALES INVOLUCRADAS EN LA FORMACIÓN DE MLP Y RECEPTORES 5-HT}

La presencia del receptor $5-\mathrm{HT}_{7}$ en áreas importantes para el aprendizaje y la memoria coincide con las estructuras de las cuales depende el automoldeamiento, que son: el núcleo basolateral de la amígdala, el área CA1 y giro dentado del hipocampo, hipotálamo, corteza parietal, temporal, occipital, retroesplenial así como núcleo del rafe medio (Meneses et al 2004; ManuelApolinar et al, 2004; Luna-Munguia et al, 2005). Por esta razón y debido a lo extenso de la metodología molecular, se analizaron únicamente 3 áreas: núcleo del rafe, hipocampo y corteza prefrontal.

El hecho de que el AS 19 facilitó la formación de la MLP en el automoldeamiento, nos permite concluir que probablemente el efecto de este agonista (AS19, $5 \mathrm{mg} / \mathrm{kg}$ ) se debió a la activación de receptores $5-\mathrm{HT}_{7}$, presentes en corteza prefrontal, hipocampo y núcleos del rafe, estructuras importantes para el aprendizaje y la memoria (Luna-Munguia, 2005) y que reciben proyecciones serotonérgicas o son sitio de origen de ellas (Jacobs, 1992). Debe observarse que respecto a una posible activación de otros receptores serotonérgicos, se carece de información sobre la afinidad del AS 19 por otros subtipos de receptores serotonérgicos (Sanin, 2003; información de Tocris).

Utilizando modelos farmacológicos de amnesia (administración sistémica 
de escopolamina un antagonista de los receptores muscarínicos y/o la dizolcipina antagonista de receptores NMDA), indujeron un déficit en la memoria, probablemente atribuible a un descenso de la actividad colinérgica y glutamatérgica (McDonald, 2004). La administración de escopolamina o dizolcipina en humanos y ratas, es considerado un modelo in vivo de amnesia que sirve para evaluar el aprendizaje y memoria (Santucci et al, 2004). Datos del laboratorio muestran que la administración de AS 19 (s.c.) inhibió o evitó los efectos amnésicos de la escopolamina y la dizolcipina, es decir, el AS19 debe prevenir la amnesia por medio de la activación del receptor $5-\mathrm{HT}_{7}$. Este efecto podría deberse a un mecanismo de autorreceptores $\left(5-\mathrm{HT}_{7}\right)$ en núcleo de rafé y de heteroreceptores $\left(5-\mathrm{HT}_{7}\right)$ presentes en terminales nerviosas de neuronas colinérgicas y glutamatérgicas en hipocampo y corteza prefrontal (Buhot et al, 2000), induciendo la liberación de acetilcolina y glutamato (en las respectivas neuronas colinérgicas y glutamatérgicas, en las mencionadas áreas), compitiendo con los antagonistas por el sitio de unión a sus respectivos receptores (escopolamina para el caso de receptores M1, M2 y M3; y dizolcipina para el caso de NMDA). Por lo tanto, la utilización del agonista potencialmente selectivo para el receptor $5-\mathrm{HT}_{7}$ facilita la formación de la memoria e inhibe los efectos inducidos por los amnésicos (escopolamina o dizolcipina).

\section{CAMBIOS DEL RNAM DEL RECEPTOR 5-HT 7 EN ANIMALES SOMETIDOS A AUTOMOLDEAMIENTO Y EN MODELOS DE AMNESIA}

La estrategia de realizar el análisis de RNAm mensajero de este receptor se debe a que es un indicador preciso de la activación de la expresión de este receptor. Sin embargo, para aseverar lo anterior se necesita analizar la densidad del receptor $5-\mathrm{HT}_{7}$ bajo estas mismas condiciones y estos datos son precedente para realizar futuros experimentos. La expresión diferencial del RNAm obtenida en este laboratorio nos sugiere que la cascada de señalización intracelular (hasta la síntesis de RNAm), fue activada por la estimulación del receptor $5-\mathrm{HT}_{7}$ (por medio de automoldeamiento y utilizando AS 19, $5 \mathrm{mg} / \mathrm{kg}$ ). Algunos de los estudios de la expresión RNAm del receptor $5-\mathrm{HT}_{7}$ reportaron que es poco abundante en estructuras cerebrales en comparación con otros subtipos de receptores serotonérgicos (Beique, 2004; Bhalla, 2002; East, 2002; Gustafson, 1996; Healy, 2000; Le Corre, 1997), sin embargo, se encontró una importante expresión del RNAm del receptor $5-\mathrm{HT}_{7}$.

Los resultados mas relevantes se observaron al comparar: a) la expresión del RNAm del receptor $5-\mathrm{HT}_{7}$ con base de la experiencia (animales entrenados y no entrenados); b) tratamientos farmacológicos (agonista $5-\mathrm{HT}_{7}$ vs. antagonista $5-\mathrm{HT} 7$; y c) expresión diferencial del RNAm del receptor 
5- $\mathrm{HT}_{7}$ en diversas estructuras (rafe, hipocampo y corteza prefrontal). Finalmente se comparó la expresión del RNAm entre las diversas condiciones y parámetros.

\section{EXPRESIÓN DEL GEN DEL RECEPTOR 5-HT (PASIVAS VS. ENTRENADAS)}

Los animales no entrenados controles, tratados con WAY100635, escopolamina o dizolcipina no muestran expresión del RNAm del receptor $5-\mathrm{HT}_{7}$, sin embargo, con la administración de AS19 y 8-OHDPAT si exhiben una expresión significativa en animales no entrenados. Esto indica que ambos agonistas estimulan el receptor $5-\mathrm{HT}_{7}$ induciendo la expresión del RNAm del receptor $5-\mathrm{HT}_{7}$ en condiciones de no entrenamiento. Sorpresivamente, la administración de SB-269970 induce expresión del RNAm del receptor $5-\mathrm{HT}_{7}$, sugiriendo que este antagonista se comporta como un agonista parcial, es decir, un fármaco que al unirse al receptor induce parcialmente una respuesta biológica. Incluso, se puede comparar que la expresión del RNAm del receptor $5-\mathrm{HT}_{7}$ es mayor en animales tratados con el SB-269970 en relación con los animales tratados con 8-OH DPAT. Estos datos son consistentes con los reportados en líneas celulares (Vermeulen, 2004, ver mas adelante).

Estos datos aportan información de cómo se comporta la expresión del RNAm del receptor 5- $\mathrm{HT}_{7}$ en animales pasivos o no entrenados (no sometidos a un aprendizaje asociativo), pero tratados farmacológicamente. Estos datos son comparables con animales que fueron tratados farmacológicamente y que fueron sometidos a un aprendizaje asociativo (automoldeamiento) y que a continuación se describen.

En los animales entrenados con automoldeamiento, se observó una expresión importante de RNAm del receptor $5-\mathrm{HT}_{7}$ en el grupo control (PG) comparado con los demás grupos entrenados. Sin embargo, este dato, comparado con los animales controles pasivos (ver arriba) nos sugiere que la adquisición de la experiencia del aprendizaje (automoldeamiento) induce la expresión del RNAm del receptor 5- $\mathrm{HT}_{7}$. El posible mecanismo que podría mediar este efecto sería que el automoldeamiento induce liberación de serotonina endógena de terminales nerviosas de neuronas serotonérgicas cuyas proyecciones estén próximas al hipocampo y corteza prefrontal (por ejemplo).

Esta liberación de serotonina estimularía al receptor $5-\mathrm{HT}_{7}$ presente en las áreas mencionadas. La serotonina debe estimular otros receptores serotonérgicos, sin embargo estos no fueron analizados.

En la curva dosis-respuesta del AS 19 observamos que la dosis con un efecto sobre la formación MLP $(5 \mathrm{mg} / \mathrm{kg})$ no induce una mayor expresión 
de RNAm del receptor $5-\mathrm{HT}_{7}$; es decir, se observa más bien una expresión atenuada con respecto al control (PG). La principal explicación de la elevada expresión de RNAm del receptor $5-\mathrm{HT}_{7}$ en los animales controles sugiere que para que se realice una formación y consolidación de la MLP es necesaria la expresión del gen del receptor $5-\mathrm{HT}_{7}$, mientras que para que se facilite la MLP (en la dosis de AS19, $5 \mathrm{mg} / \mathrm{kg}$ ) es necesaria una atenuación de la expresión RNAm del receptor $5-\mathrm{HT}_{7}$ respecto del control. Esto indica que ocurre una modulación en la expresión de genes por la estimulación con fármacos y/o por un aprendizaje asociativo (automoldeamiento) in vivo. Sin embargo, también es posible sugerir que este efecto puede deberse a que los animales fueron sacrificados después de la prueba es decir, 48 horas después del entrenamiento y la administración de los fármacos. El tiempo en el cual se realizan los eventos de la cascada de señalización intracelular después de la activación de receptores no esta claro, pues solo se analizó la expresión del RNAm del receptor 5- $\mathrm{HT}_{7}$ a un solo tiempo: 48 horas después de recibidos los fármacos y las sesiones de prueba de automoldeamiento. Por otro lado, existe otra posible explicación para la expresión atenuada del RNAm del receptor $5-\mathrm{HT}_{7}$ en animales entrenados con automoldeamiento y tratados con AS19 $(5 \mathrm{mg} / \mathrm{kg})$. Es posible que la expresión del RNAm este parcialmente disminuida debido a una desensibilización del receptor $5-\mathrm{HT}_{7}$ relacionada a la doble estimulación (por aprendizaje y el AS 19).

Anteriormente, se entendía que el agonista se unía al receptor modificándolo y activando procesos en la membrana y el antagonista solo actuaba interfiriendo con la unión del agonista al receptor, compitiendo por afinidad al receptor y evitando su activación (antagonismo competitivo). Sin embargo, se ha encontrado también que los receptores tienden a permanecer parcialmente en su forma activa (actividad constitutiva) y el agonista los estabiliza para mantener este estado en forma más intensa y prolongada (Kenakin, 2001; Vermeulen, 2005; Andressen, 2005 ).

Lo que no esta claro en este trabajo, es si el aprendizaje induce la liberación de serotonina, misma que estimule el receptor $5-\mathrm{HT}_{7}$ y el AS 19 también lo estimule (obteniendo una doble estimulación) o, el receptor $5-\mathrm{HT}_{7}$ está constitutivamente activo y la estimulación con el aprendizaje y el AS 19 inducen un efecto negativo que atenúe la respuesta biológica (es decir, una atenuación de la expresión de RNAm del receptor $5-\mathrm{HT}_{7}$ ).

En cambio, los animales tratados con WAY 100635 expresan el RNAm del receptor $5-\mathrm{HT}_{7}$, este dato confirma que el WAY 100635 no tiene afinidad por el receptor $5-\mathrm{HT}_{7}$ porque no bloqueo expresión del RNAm, porque muy probablemente el aprendizaje por automoldeamiento estimulo el receptor $5-\mathrm{HT}_{7}$ (ver mas arriba), dicha estimulación no fue bloqueada por el WAY 100635. En contraparte, en los animales sometidos a automoldeamiento y tratados con SB-269970 no se aprecia la expresión del RNAm del receptor $5-\mathrm{HT}_{7}$, lo que 
nos sugiere que el SB-269970 bloqueo la expresión del RNAm del receptor 5$\mathrm{HT}_{7}$, estimulado por el aprendizaje por automoldeamiento. Además, la administración de WAY100635 más AS 19 no modifica la expresión, mientras que la administración de SB-269970 más AS 19 bloquea la expresión del RNAm del receptor $5-\mathrm{HT}_{7}$. Estos datos, en conjunto sugieren que el WAY 100635 no tiene afinidad por los receptores $5-\mathrm{HT}_{7}$, ya que no bloquean su estimulación. Los animales tratados con WAY100635 más SB-269970 tampoco muestran expresión del RNAm del receptor $5-\mathrm{HT}_{7}$.

Recientemente se reportó una expresión diferencial del RNAm del receptor $5-\mathrm{HT}_{7}$ en líneas de células (Guthrie et al, 2005) donde expresan este receptor y utilizan fármacos para estimular y bloquear este mismo receptor. Utilizan 5-CT como agonista y el SB-269970 como antagonista. En sus resultados, evalúan la expresión del RNAm del receptor $5-\mathrm{HT}_{7}$, donde la expresión más fuerte se encontró en células con el receptor no estimulado (los controles). En las células con el receptor estimulado (5-CT) encuentran una expresión del RNAm atenuada.

Finalmente, en células tratadas con 5-CT y con SB-269970 encuentran bloqueada la expresión del RNAm del receptor $5-\mathrm{HT}_{7}$.

Los resultados de ese trabajo (in vitro) coinciden con los encontrados en este proyecto (ex vivo) porque la estimulación del receptor $5-\mathrm{HT}_{7}$ con AS 19 mostró una atenuación en la expresión del RNAm del receptor $5-\mathrm{HT}_{7}$ que fue bloqueada por el antagonista (SB 269970).

\section{EL EFECTO DE LA AMNESIA EN LOS RECEPTORES 5-HT}

La amnesia con escopolamina o dizocilpina fue inhibida por la administración del AS 19 y también restableció la expresión del RNAm del receptor $5-\mathrm{HT}_{7}$; siendo mayor el efecto en el modelo de escopolamina (área de rafe e hipocampo), mostrando así que en dicho efecto hay una interacción más importante entre el sistema serotonérgico y el sistema colinérgico que con respecto al sistema glutamatérgico.

Hay que destacar que en la literatura describen que la actividad colinérgica se ha detectado en áreas específicas del cerebro, que coinciden con las que expresan el RNAm del receptor 5- $\mathrm{HT}_{7}$ (rafe, hipocampo, corteza). Por lo que el reestablecimiento en la expresión del RNAm del receptor $5-\mathrm{HT}_{7}$ podría deberse a la presencia de heterorreceptores $5-\mathrm{HT}_{7}$ en neuronas colinérgicas ( $\mathrm{y}$ en menor grado respecto al sistema glutamatérgico) promoviendo un mecanismo de modulación. Por otro lado, Healy y colaboradores (2000) en animales sin manipulación conductual encontraron que el bloqueo de receptores NMDA con dizolcipina (MK-801), altera la expresión del RNAm del receptor $5-\mathrm{HT}_{6}$ pero no del $5-\mathrm{HT}_{7}$ en regiones del hipocampo. 
Estos resultados proporcionaron evidencia de una interacción entre el sistema glutamatérgico y serotonérgico y es consistente con los datos presentes.

\section{ÁREAS CEREBRALES, MLP, Y CAMBIOS DEL RNAM DEL RECEPTOR 5-HT}

En animales sometidos al automoldeamiento encontramos una importante expresión del RNAm del receptor $5-\mathrm{HT}_{7}$ en rafe e hipocampo y menos intensa en CPF. Estos datos sugieren que la síntesis de receptores $5-\mathrm{HT}_{7}$ debe ser, en orden decreciente de más abundante en rafe respecto a hipocampo y corteza prefrontal. Además, estos datos sugieren un papel mas preponderante de receptores $5-\mathrm{HT}_{7}$ presinápticos (auto) que los postsinápticos (heteroreceptores) tanto en la formación de la MLP, como cuando ésta se facilita con fármacos, porque la expresión es mayor en el área del rafe comparada con las de las otras áreas (hipocampo, CPF). Los animales controles (PG) pasivos (no entrenados) no exhiben expresión ni en rafe ni en hipocampo, pero si en CPF. Esto sugiere que el receptor $5-\mathrm{HT}_{7}$ debe estar activo o estimulado en esa área bajo condiciones de no entrenamiento. Los animales controles (PG) entrenados en todas las áreas exhiben la expresión de RNAm mas intensa comparada con los otros tratamientos. Esto sugiere la participación de las 3 áreas analizadas (rafe, hipocampo, CPF) y la estimulación del receptor 5- $\mathrm{HT}_{7}$ por medio de automoldeamiento es importante para la consolidación de la MLP. Los animales pasivos y tratados con el AS19 exhiben una expresión moderada del gen del receptor en las áreas de hipocampo y CPF, siendo más importante esta expresión en núcleo de rafe.

El núcleo del rafe es el origen de las proyecciones serotonérgicas razón por la cual, sugerimos que está más fuertemente expresado el gen del receptor $5-\mathrm{HT}_{7}$. En animales entrenados con automoldeamiento y tratados con el AS 19 exhiben un patrón de expresión muy similar al caso anterior, aunque la expresión es más intensa. Sin embargo esta expresión es menor comparada los animales controles (PG) entrenados. Por esta razón, suponemos que la doble estimulación del receptor $5-\mathrm{HT}_{7}$ (aprendizaje y con el AS 19) en las 3 áreas estudiadas induce la atenuación del gen del receptor $5-\mathrm{HT}_{7}$.

Esto puede estar explicado por la muy posible doble estimulación del receptor $5-\mathrm{HT}_{7}$ (por aprendizaje y automoldeamiento), siendo el núcleo del rafe el que expresa más intensamente el RNAm del receptor $5-\mathrm{HT}_{7}$, al menos bajo las presentes condiciones de entrenamiento.

Los animales sin aprendizaje tratados con SB-299970 expresan el RNAm del receptor $5-\mathrm{HT}_{7}$ en área de rafe e hipocampo. Esto nos sugiere, por un lado que el SB-269970 se comporta como un agonista parcial (bajo estas condiciones) y que tiene efecto en rafe e hipocampo pero no en CPF. 
En animales entrenados y tratados con SB-269970 esta bloqueada la expresión el RNAm del receptor $5-\mathrm{HT}_{7}$, en las 3 áreas. Este mismo patrón se encuentra en las 3 áreas en animales entrenados y tratados con AS 19 y SB-269970, lo que nos confirma que el SB-269970 bloquea la estimulación del receptor $5-\mathrm{HT}_{7}$ y la expresión del gen inducido por el aprendizaje y por el AS 19 (ver figura 5).

NO ENTRENADOS
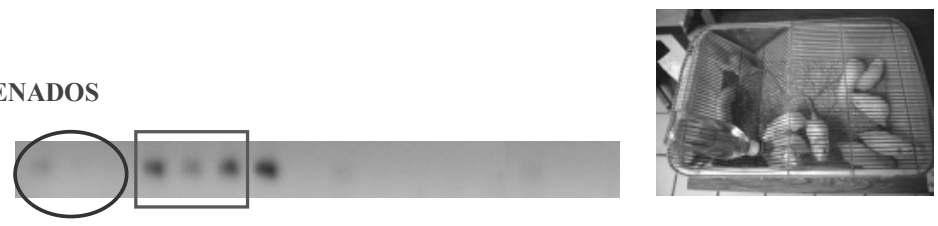

ENTRENADOS Y CON TRATAMIENTO FARMACOLOGICO

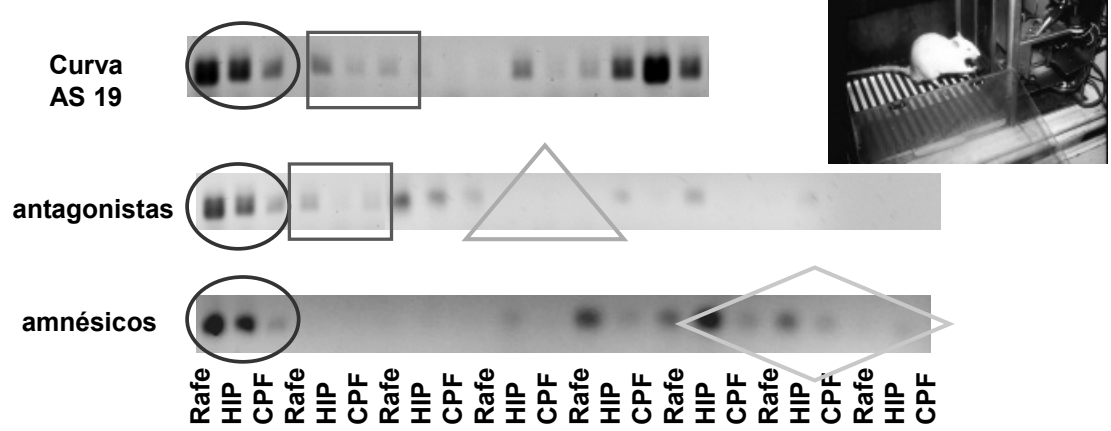

Figura 5. Análisis de la comparación de la expresión del RNAm del receptor 5-HT $\mathrm{T}_{7}$ entre grupos (entrenadas vs. no entrenadas), por tratamiento y por estructuras. Los círculos muestran los animales controles, los cuadros animales tratados con AS 19, el rectangulo animales tratados con SB269970 y el rombo animales tratados con amnésicos y AS 19.

También otros estudios han reportado cambios en la expresión del gen del receptor $5-\mathrm{HT}_{7}$, mostrando que la expresión del gen de este receptor puede ser aumentada por adrenalectomia (Le Corre, 1997;Yau, 1997), estrés agudo (Yau, 2001) y la administración de p-cloroanfetamina (neurotoxina que destruye terminales serotonérgicas) en tallo cerebral (Garcia-Osta et al, 2000).

Otros estudios sugieren que la expresión del gen de este receptor puede ser disminuida con el tratamiento con un inhibidor de la recaptura de 5-HT, fluoxetina $5 \mathrm{mg} / \mathrm{kg}$ por 21 días (Sleight et al, 1995). Finalmente, algunos estudios no han encontrado cambios en expresión del gen del receptor $5-\mathrm{HT}_{7}$ con tratamiento con amitriptalina (antidepresivo tricíclico inhibidor de la re- 
captura de NA y 5-HT) por 10 semanas (Yau et al, 1999) y la administración de choques electroconvulsivos (Burnet, 1999). Todos los trabajos descritos anteriormente analizan la expresión del receptor $5-\mathrm{HT}_{7}$ en varias estructuras del SNC en ratas pero en especial en regiones del hipocampo.

Interesantemente, dos trabajos reportaron asociaciones funcionales. El primero describe la expresión del RNAm en distintas estructuras cerebrales durante el desarrollo post-natal, sugiriendo un importante papel de la expresión del gen del receptor $5-\mathrm{HT}_{7}$ para el desarrollo comparado con ratas adultas (Vizuete et al, 1997). El segundo describe una regulación en el desarrollo del potencial de membrana en la corteza prefrontal y la expresión del RNAm del gen del receptor $5-\mathrm{HT}_{7}$ entre otros subtipos serotonérgicos (Beique et al, 2004).

Asimismo, el presente trabajo demostró una asociación funcional entre el proceso de aprendizaje y formación de memoria (utilizando automoldeamiento), la administración de fármacos (agonistas y antagonistas selectivos) y la expresión diferencial del gen del receptor $5-\mathrm{HT}_{7}$.

Los presentes resultados de la expresión del gen del receptor $5-\mathrm{HT}_{7}$ en conjunto, sugieren que el grado de expresión de este gen podría estar controlado por las vías de señalización implicadas en la formación de la MLP comentadas más arriba. Por lo tanto, sería posible que la expresión diferencial de RNAm del receptor $5-\mathrm{HT}_{7}$, se deba a que la activación de estos responden a cambios en la concentración de ligando (por ejemplo, AS 19), receptores pre-existentes y a la experiencia del aprendizaje; así iniciando, modificaciones en la vía de transducción de señales, los cuales, a su vez, provocarían una modulación en la expresión del RNAm y posteriormente en la proteína del receptor. Esta noción es consistente con la evidencia que aportan los trabajos descritos anteriormente, así como con el proceso de aprendizaje y de consolidación de memoria (este trabajo) que inducirían cambios en la liberación de serotonina endógena. Estos cambios regularían la función del receptor a corto plazo (por desensibilización) o a largo plazo (síntesis de proteínas y receptores). Notablemente también la manipulación farmacológica con agonistas y antagonistas serotonérgicos modularía la expresión de genes y la formación de la memoria. El siguiente esquema ilustra estas nociones con los posibles eventos moleculares ocurriendo en rafe, hipocampo y/o corteza prefrontal (ver figura 6)

\section{PERSPECTIVAS}

Los datos de la MLP mostraron una facilitación en la formación de la memoria por la estimulación de receptores $5-\mathrm{HT}_{7}$ con un nuevo agonista y potencialmente selectivo. Los datos de análisis de la expresión del gen mostraron una 


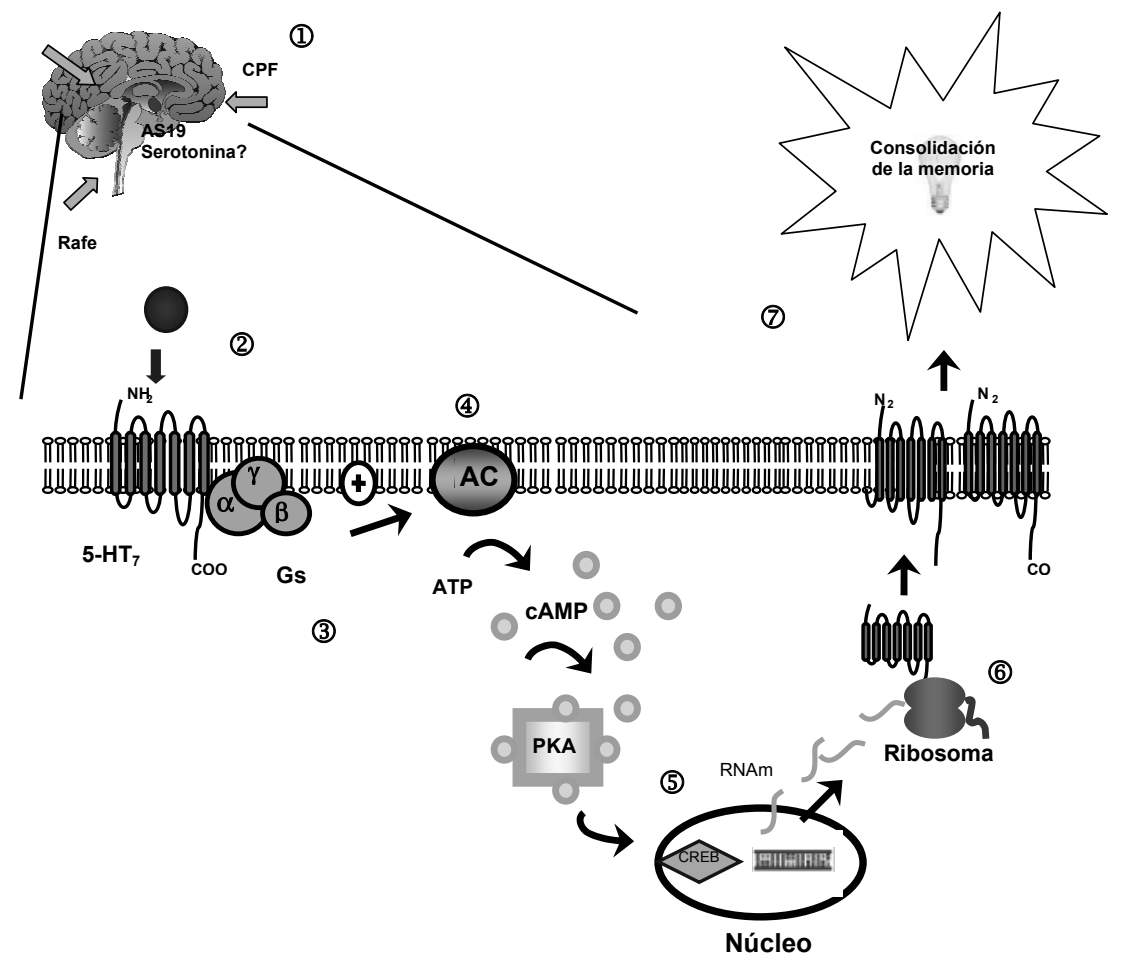

Figura 6. Eventos moleculares que ocurren durante la activación del receptor 5-HT . (1) Existen cambios en la expresión de RNAm en las estructuras de Rafe, Hipocampo y CPF. (2) El AS 19 activa al receptor 5-HT, el cual esta acoplado a proteínas Gs (3) esta se disocia y activa (4) al adenilato ciclasa (AC). Aumenta el AMPc intracelular (5) y activa a la PKA. Esta es capaz de translocarse al núcleo y activar al CREB. Se induce la trascripción de genes específicos a RNAm y posteriormente la traducción a proteínas (6). Finalmente, estas proteínas debieran expresarse como receptores en la membrana de la neurona y consolidar así la memoria (7). 
modulación del gen del receptor $5-\mathrm{HT}_{7}$ inducida por tratamiento con fármacos (agonistas y antagonistas del receptor $5-\mathrm{HT}_{7}$ ) y por medio de un aprendizaje asociativo (automoldeamiento) en estructuras específicas del cerebro (núcleo del rafe, el hipocampo y la corteza prefrontal).

Los datos presentes demuestran la utilidad de estudiar en los mismos animales el aprendizaje, la manipulación farmacológica y la expresión de genes sobretodo en el contexto de que los experimentos que evalúan elementos moleculares del aprendizaje y memoria en mamíferos son escasos, poco se ha hablado de la dificultad para comparar los resultados de distintos experimentos donde utilizan distintas pruebas conductuales de aprendizaje y memoria (water maze, aversión pasiva, CAS, entre otras).

La utilización de diferentes especies (variación sistemática), sexo y uso arbitrario de grupos control, dificultan el análisis del fenómeno del aprendizaje y la memoria.

Parece importante dilucidar cómo varía la formación de la memoria frente a distintas dosis de agonistas y/o antagonistas, el discernimiento de estos fármacos (Wesolowska, 2002) la utilización de distintas vías de administración (ej: intracerebral vs. sistémica) y estudios de la cinética de los mismos durante las pruebas conductuales ayudaran a determinar la naturaleza de los eventos.

Todos los datos anteriores nos sugieren que el receptor $5-\mathrm{HT}_{7}$ tiene un papel importante en la formación de la memoria y en la memoria disfuncional, esto quiere decir que los datos ofrecen información para el diseño de futuros experimentos para entender el papel funcional de este receptor en la memoria (normal y disfuncional).

\section{BIBLIOGRAFÍA}

1. Alberini C. M. Mechanisms of memory stabilization: are consolidation and reconsolidation similar or distinct processes? Trends Neurosci. 28 (1):51-56., 2005.

2. Albright M. I.; Posner T. D.; Kandel E. R. Cognitive neuroscience. Curr Opin Neurobiol. 10 (5):612-624., 2000.

3. Andressen K. W.; Norum J. H.; Levy F. O.; Krobert K.. Activation of adenylyl cyclase by endogenous Gs-coupled receptors in HEK293 cells is attenuated by 5HT7 receptor expression. Mol Pharmacol. 27, 2005.

4. Baumgarten H. G. and M. Göthert. Serotonergic neurons and 5-HT receptors in the CNS, Alemania:Springer-Verlag, 767 pages, 2000.

5. Beique J. C.; Campbell B.; Perring P; Hamblin M. W; Walker P.; Mladenovic L.; Andrade R. Serotonergic regulation of membrane potential in developing rat prefrontal cortex: coordinated expression of 5-hydroxytryptamine: 5-HT1A, 5-HT2A, and 5-HT7 receptors. J Neurosci. 24 (20):4807-4817, 2004. 
6. Berger W. J; Caliguri J. E.; and Frick M K. Neurochemical systems involved in learning and memory. In: Neurobiology of Mental IIIness, edited by D Charney S and E Nestler, New York: Oxford University Press, p. 813-820, 2004.

7. Bhalla P; Saxena P. R.; Sharma H. S. Molecular cloning and tissue distribution of $m R N A$ encoding porcine 5-HT7 receptor and its comparison with the structure of other species. Mol Cell Biochem. 238 (1-2):81-88., 2002.

8. Bradley P. B.; Engel G.; Feniuk W. Fozard J. R.; Humphrey P. P.; Middlemiss D. N.; Mylecharane E. J.; Richardson B. P.; Saxena P. R. Proposals for the classification and nomenclature of functional receptors for 5-hydroxytryptamine. Neuropharmacology 25 (6):563-576, 1986.

9. Buckner R L. Memory and Executive Function in Aging and AD: Multiple Factors that Cause Decline and Reserve Factors that Compensate. Neuron 44:195-208, 2004.

10. Buhot MC. Serotonin receptors in cognitive behaviors. Curr Opin Neurobiol. 7 (2):243-254, 1997.

11. Buhot M C.; Malleret G.; Segu L. Serotonin receptors and cognitive behaviour-an update. IDrugs. 2 (5):426-437, 1999.

12. Buhot M C.; Martin S.; Segu L. Role of serotonin in memory impairment. Ann Med. 32 (3):210-221., 2000.

13. Burnet P W; Sharp T.; LeCorre S M; Harrison PJ. Expression of 5-HT receptors and the 5-HT transporter in rat brain after electroconvulsive shock. Neurosci Lett. 277 (2):79-82, 1999.

14. Cahill L.; McGaugh J. L.; Weinberger N. M. The neurobiology of learning and memory: some reminders to remember. Trends Neurosci. 24 (10):578-581, 2001.

15. Cammarota M.; Bevilaqua L R.; Barros D M.; Vianna M R.; Izquierdo LA.; Medina $\mathrm{J} \mathrm{H}$.; Izquierdo I. Retrieval and the extinction of memory. Cell Mol Neurobiol. 25 (3-4):465-474, 2005.

16. Cavallaro S.; D'Agata V.; Manickam P.; Dufour F.; Alkon D L. Memory-specific temporal profiles of gene expression in the hippocampus. Proc Natl Acad Sci U S A. 99 (25):16279-16284, 2002.

17. Cavallaro S.; Schreurs B. G.; Zhao W.; D'Agata V.; Alkon D L. Gene expression profiles during long-term memory consolidation. Eur J Neurosci. 13 (9):18091815, 2001.

18. Chen J J.; Vasko M R.; Wu X.; Staeva T P.; Baez M.; Zgombick J M. Nelson D. L.. Multiple subtypes of serotonin receptors are expressed in rat sensory neurons in culture. J Pharmacol Exp Ther. 287 (3):1119-1127, 1998.

19. Dash P K.; Hebert A E.; Runyan JD. A unified theory for systems and cellular memory consolidation. Brain Res Rev 45 (1):30-37, 2004.

20. Davis H. and Hurwwitz H. Operant-Pavlovian interactions, New York: Lawrance Erlbaum, 327 pages, 1977.

21. Davis $\mathrm{H}$ and Squire L. Protein synthesis and memory: a review. Psychol Bull. Nov;96(3):518-59. 1984

22. Dever T E. Gene-specific regulation by general translation factors. Cell. 108 (4):545-556, 2002.

23. Dickinson A. Teorías actuales del aprendizaje animal, Madrid, editorial Debate, 285 páginas, 1984. 
24. Domjan M. Principles of learning and behavior. New York: Wadsworth Publishing, 1998.

25. East S Z.; Burnet P. W.; Kerwin R. W.; Harrison P. J. An RT-PCR study of 5-HT(6) and 5-HT(7) receptor $m R N A$ s in the hippocampal formation and prefrontal cortex in schizophrenia. Schizophr Res. 57 (1):15-26., 2002.

26. Garcia-Osta A.; Frechilla D.; Del Rio J. Effect of p-chloroamphetamine on 5-HT1A and 5-HT7 serotonin receptor expression in rat brain. J Neurochem. 74 (5):17901797, 2000.

27. Goodman and Gilman. Las bases Farmacológicas de la Terapéutica, Mc Graw Hill, 2002.

28. Gustafson E L.; Durkin M M.; Bard J A.; Zgombick J.; Branchek T A. A receptor autoradiographic and in situ hybridization analysis of the distribution of the 5-ht7 receptor in rat brain. Br J Pharmacol. 117 (4):657-666, 1996.

29. Guthrie CR; Murray AT; Franklin AA; Hamblin MW. Differential Agonist-Mediated Internalization of the Human 5-HT7 Receptor Isoforms. J Pharmacol Exp Ther., 2005

30. Healy D J.; Meador-Woodruff J H. lonotropic glutamate receptor modulation preferentially affects NMDA receptor expression in rat hippocampus. Synapse. 38 (3):294-304, 2000.

31. Heidmann DE; Metcalf MA; Kohen R; Hamblin MW.. Four 5-hydroxytryptamine7 (5-HT7) receptor isoforms in human and rat produced by alternative splicing: species differences due to altered intron-exon organization. J Neurochem 68 (4):1372-1381, 1997.

32. Holmberg D.; Sohn R.; Leideborg P.; Caldirola P.; Zlatoidsky S. Novel 2-aminotetralin and 3-aminochroman derivatives as selective serotonin $5-H T_{7}$ receptor agonists and antagonists. J Med Chem 47:3927-3930, 2004

33. Hoyer D.; Hannon J.; Martin G. Molecular, pharmacological and functional diversity of 5-HT receptors. Pharmacology, Biochemistry and Behavior 71:533-554, 2002.

34. Igaz LM; Bekinschtein P; Vianna MM; Izquierdo I; Medina JH. Gene expression during memory formation. Neurotox Res 6 (3):189-204, 2004.

35. Igaz LM.; Vianna MR.; Medina JH.; Izquierdo I. Two time periods of hippocampal mRNA synthesis are required for memory consolidation of fear-motivated learning. J Neurosci. 22 (15):6781-6789, 2002.

36. Izquierdo LA.; Barros DM; Vianna MR; Coitinho A; DeDavid E; Silva T; Choi H.; Moletta B; Medina JH; Izquierdo I. Molecular pharmacological dissection of shortand long-term memory. Cell Mol Neurobiol. 22 (3):269-287, 2002.

37. Jacobs B. L Azmitia E. C. Structure and function of the brain serotonin system. Physiol.Rev. 72:165-229, 1992.

38. Kandel ER. The molecular biology of memory storage: a dialog between genes and synapses. Biosci Rep 5:565-611, 2001.

39. Kehoe JM; Macrae M. Fundamental Behavioral Methods and Findings in Classical Conditioning. 171-231, 2003.

40. Kenakin T. Inverse, protean, and ligand-selective agonism: matters of receptor conformation. FASEB J. (3):598-611, 2001.

41. Klann E.; Dever T E. Biochemical mechanisms for translational regulation in synaptic plasticity. Nat Rev Neurosci. 5 (12):931-942, 2004. 
42. Kopelman MD. Disorders of memory. Brain 125:2152-2190, 2002.

43. Lamprecht R. CREB: a message to remember. Cell Mol Life Sci. 55 (4):554-563, 1999.

44. Lamprecht R.; Hazvi S.; Dudai Y. cAMP response element-binding protein in the amygdala is required for long- but not short-term conditioned taste aversion memory. J Neurosci.1997 17 (21):8443-8450, 1997.

45. Lamprecht R.; LeDoux J. Structural plasticity and memory. Nat Rev Neurosci. 5 (1):45-54, 2004.

46. Le Corre S.; Sharp T.; Young A H.; Harrison P J. Increase of 5-HT7 (serotonin-7) and 5-HT1A (serotonin-1A) receptor mRNA expression in rat hippocampus after adrenalectomy. Psychopharmacology (Berl). 130 (4):368-374, 1997.

47. Leil TA; Ossadtchi A; Cortes JS; Leahy RM.; Smith DJ. Finding new candidate genes for learning and memory. J Neurosci Res. 68 (2):127-137, 2002.

48. Leil TA; Ossadtchi A; Nichols TE; Leahy RM; Smith DJ. Genes regulated by learning in the hippocampus. J Neurosci Res. 71 (6):763-768, 2003.

49. Lovenberg TW; Baron BM; De Lecea L; Miller JDM; Prosser RA; Rea MA; Foye PE; Racke M; Slone AL; Siegel BW. A novel adenylyl cyclase-activating serotonin receptor (5-HT7) implicated in the regulation of mammalian circadian rhythms. Neuron 3:449-458, 1993.

50. Luna-Munguia H.; Manuel-Apolinar L.; Rocha L.; Meneses A. 5-HT1A receptor expression during memory formation. Psychopharmacology (Berl). 181 (2):309318, 2005.

51. Lynch G. Memory enhancement: the search for mechanism-based drugs. Nature neurosciences 5:1035-1038, 2002.

52. Manuel-Apolinar L; Meneses A. 8-OH-DPAT facilitated memory consolidation and increased hippocampal and cortical cAMP production. Behav Brain Res. 148 (12):179-184, 2004.

53. Manuel Apolinar L. Influencia de la consolidación de la memoria sobre los receptores serotonérgicos en el sistema nervioso central de la rata. Tesis de Doctorado. Escuela Superior de Medicina del Instituto Politécnico Nacional. 1-146, 2004.

54. McDonald RJ; Devan BD; Hong NS. Multiple memory systems: the power of interactions. Neurobiol Learn Mem 82 (2):333-346, 2004.

55. Meneses A; Huerta A G; Valdez D. 5-HT system function on short- \& long- term memory. Cartel en congreso. The International Journal of neuropsychopharmacology. Paris, 2004.

56. Meneses A. El efecto de bloqueo en automoldeamiento positivo. 1987. Tesis de licenciatura. UNAM, 54 págs.

57. Meneses A. A pharmacological analysis of an associative learning task: $5-H T(1)$ to 5-HT(7) receptor subtypes function on a pavlovian/instrumental autoshaped memory. Learn Mem.2003 Sep-Oct 10 (5):363-372, 2003.

58. Meneses A; Manuel-Apolinar L; Rocha L; Castillo E; Castillo C. Expression of the $5-H T$ receptors in rat brain during memory consolidation. Behavioural Brain Research 152: 425-436, 2004.

59. Meneses A; Hong E. A pharmacological analysis of serotonergic receptors: Effects of their activation of blockade in learning. Progress in Neuro-Psychopharmacology and Biological Psychiatry 21 (2):273-296, 1997. 
60. Meneses A; Terrón JA. Role of $5-H T_{1 \mathrm{~A}}$ and $5-H T_{7}$ receptors in the facilitatory response induced by 8-OH-DPAT on learning consolidation. Behavioural Brain Research 121 (1-2):21-28, 2001.

61. Micheau J; Riedel G. Protein kinases: which one is the memory molecule? Cell Mol Life Sci. 55 (4):534-548, 1999.

62. Morton J; Hammersley RH; Bekerian DA. Headed records: a model for memory and its failures. Cognition. 20 (1):1-23, 1985.

63. Moser M B. Making more synapses: a way to store information? Cell Mol Life Sci. 55 (4):593-600., 1999.

64. Moyano S; Del Rio J; Frechilla D. Role of hippocampal CaMKII in serotonin 5$H T(1 A)$ receptor-mediated learning deficit in rats. Neuropsychopharmacology 29 (12):2216-2224, 2005.

65. Myhrer T. Neurotransmitter systems involved in learning and memory in the rat: a meta-analysis based on studies of four behavioral tasks. Brain Research Reviews 41 (2-3):268-287, 2003.

66. Nader K. Memory traces unbound. Trends Neurosci 26 (2):65-72, 2003.

67. Perez-Garcia G.; Meneses A. Effects of the potential 5-HT7 receptor agonist AS 19 in an autoshaping learning task. Behav Brain Res. 163 (1):136-140, 2005.

68. Riedel G; Micheau J. Introduction: molecular mechanisms of memory formation-from receptor activation to synaptic changes. Cell Mol Life Sci. 55 (4):521-524, 1999.

69. Robles Y; Vivas-Mejia PE; Ortiz-Zuazaga HG; Felix J; Ramos X; Pena de Ortiz S. Hippocampal gene expression profiling in spatial discrimination learning. Neurobiol Learn Mem. 80 (1):80-95, 2003.

70. Rodrigues S; Schafe G; and LeDoux J. Molecular Mechanisms Underlying Emotional Learning and Memory in the Lateral Amygdala. Neuron 44:75-91, 2004.

71. Routtenberg A; Rekart JL. Post-translational protein modification as the substrate for long-lasting memory. Trends Neurosci. 28 (1):12-19., 2005.

72. Sambrook J and Russell D. Molecular Cloning A Laboratory Manual, New York: Cold Spring Laboratory Press, 2001.

73. Santucci AC. and Haroutunian V. Pharmacological and transgenic animal models of Alzheimer's disease. In: Neurobiology of mental illness, edited by E. J. Nestler D.S.Charney, New York:Oxford University press, 791-806, 2004.

74. Shen Y; Monsma FJ Jr; Metcalf MA; Jose PA; Hamblin MW; Sibley DR. Molecular cloning and expression of a 5-hydroxytryptamine 7 serotonin receptor subtype. $J$ Biol Chem 268 (24):18200-18204, 1993.

75. Shors TJ;. Beylin AV; Wood GE; Gould E. The modulation of Pavlovian memory. Behav Brain Res 110 (1-2):39-52, 2000.

76. Slassi A; Methvin I; Xin T. Recent progress in $5 \mathrm{H}-\mathrm{T}_{7}$ receptors: potential treatment of central and peripheral nervous system diseases. Expert Opinion Ther. Patents 14 (7):1009-1027, 2004.

77. Sleight AJ; Carolo C; Petit N; Zwingelstein C; Bourson A. Identification of 5-hydroxytryptamine 7 receptor binding sites in rat hypothalamus: sensitivity to chronic antidepressant treatment. Mol Pharmacol. 47 (1):99-103, 1995.

78. Stork O; Welzl H. Memory formation and the regulation of gene expression. Cell Mol Life Sci. 55 (4):575-592, 1999.

79. Szapiro G; Galante JM; Barros DM; Levi de Stein M; Vianna MR; Izquierdo LA; 
Izquierdo I; Medina JH. Molecular mechanisms of memory retrieval. Neurochem Res. 27 (11):1491-1498, 2002.

80. Thomas DR; Hagan JJ. 5-HT7 receptors. Curr Drug Targets CNS Neurol Disord.2004 Feb; 3 (1):81-90, 2004.

81. Tischmeyer W; Grimm R. Activation of immediate early genes and memory formation. Cell Mol Life Sci. 55 (4):564-574, 1999.

82. Van Wijngaarden I; Tulp MT; Soudijn W. The concept of selectivity in 5-HT receptor research. Eur J Pharmacol. 188 (6):301-312, 1990.

83. Varnas K; Thomas DR; Tupala E; Tiihonen J; Hall H. Distribution of 5-HT7 receptors in the human brain: a preliminary autoradiographic study using [3H]SB269970. Neurosci Lett. 367 ((3)):313-316, 2004.

84. Vermeulen E S; Van Smeden M; Schmidt AW; Sprouse J S; Wikstrom H V; Grol CJ. Novel 5-HT7 receptor inverse agonists. Synthesis and molecular modeling of arylpiperazine and 1,2,3,4-tetrahydroisoquinoline-based arylsulfonamides. J Med Chem. 47 (22):5451-5466, 2004.

85. Vermeulen, Erik Sander. Characterization of the 5-HT7 receptor: synthesis and molecular modeling of ligands and the receptor. Tesis de doctorado. University of Groningen, pages 1-209, 2005.

86. Vianna MR; Alonso M; Viola H; Quevedo J; De Paris F; Furman M; De Stein $\mathrm{ML}$; Medina JH; Izquierdo I. Role of hippocampal signaling pathways in long-term memory formation of a nonassociative learning task in the rat. Learn Mem. 7 (5):333-340, 2000.

87. Vizuete M L; Venero J L; Traiffort E; Vargas C; Machado A; Cano J. Expression of 5-HT7 receptor mRNA in rat brain during postnatal development. Neurosci Lett. 227 (1):53-56, 1997.

88. Wesolowska A. In the search for selective ligands of 5-HT5, 5-HT6 and 5-HT7 serotonin receptors. Pol J Pharmacol. 54 (4):327-341, 2002.

89. Yau JL; Noble J; Seckl JR. Acute restraint stress increases $5-H T_{7}$ receptor $m R N A$ expression in the rat hippocampus. Neurosci Lett. 309 (3):141-144, 2001.

90. Yau JL; Noble J; Widdowson J; Seckl JR. Impact of adrenalectomy on 5-HT6 and 5-HT7 receptor gene expression in the rat hippocampus. Brain Res Mol Brain Res. 45 (1):182-186, 1997.

91. Yau JL; Olsson T; Noble J; Seckl J R. Serotonin receptor subtype gene expression in the hippocampus of aged rats following chronic amitriptyline treatment. Brain Res Mol Brain Res. 70 (2):282-287, 1999. 